\title{
SEGMENTAL PHONOLOGICAL PROPERTIES IN THAKALI: A TYPOLOGICAL PERSPECTIVE
}

\begin{abstract}
Dan Raj Regmi, Ambika Regmi
Thakali, a Tibeto-Burman language spoken in Nepal, exhibits some typologically interesting properties in the domain of segmental phonology. It presents a rich inventory of 33 segmental consonant phonemes and a set of six monophthongal vowels with murmured voice (i.e., breathy) counterparts. The syllable structure at the maximum consists of $(C)(X) V(C)$, where X stands for a glide or liquid phoneme. Thakali as a Bodish language contains retroflex series as well as distinct alveolar fricatives and affricates and lacks phonemic voicing contrasts. As a member of the Gurungic cluster of West Bodish sub-section, Thakali shares such properties with other WestBodish languages,viz., Chantyal, Manange, Gurung, Magar Kaike, Ghale, Seke, Nar-Phu, Western Tamang and Eastern Tamang. Unlike a Bodish language, Thakali lacks phonemically nasalized vowels. Thakali, like Chantyal, presents contrasts involving voice onset time and murmur. Such contrasts are attested in stops, affricates, fricatives, trills/taps and laterals in Thakali. However, unlike Chantyal, Thakali contains murmured trill/tap and murmured lateral with voiceless onset like Seke and Nar-Phu. Such properties are exclusively absent in other West Bodish languages. While uplifting Thakali, a shifting language, from sustainable identity to sustainable orality, such properties typical in South Asia (Noonan, 2003a: 316) have to be fully maintained.
\end{abstract}

Keywords: aspirated, murmured, retroflex, cluster, syllable, typological

\section{Background}

This paper investigates some basic segmental phonological properties in Thakali [ths] and compares them with those observed in the West Bodish languages (i.e., Ghale, Magar Kaike, Western Tamang, Eastern Tamang, Chantyal, Gurung, Manange, Seke and NarPhu) from a typological perspective ${ }^{1}$. Thakali, an independent Tibeto-Burman language, is mainly spoken in Mustang, Kaski, Kathmandu and Rupandehi districts of Nepal (CBS 2012). It is natively referred to as tamay kai (tomay 'Thakali' and kai 'language'). It is spoken by $39.7 \%$ (i.e. 5,242) of the total ethnic population (CBS 2012).

In Eppele et al. (2012), Thakali has been categorized as a shifting language. It is gradually losing its speakers mainly because of massive migration and intense language contact with Nepali. Moreover, the child-bearing generation is not effectively motivated to transmit this language to the children in this speech community (Regmi 2017). Webster (2007) has also ascribed Thakali as a seriously endangered language. A few preliminary works are available dealing with some phonological properties in Thakali. They include

\footnotetext{
${ }^{1}$ West Bodish languages include Ghale, Magar Kaike, Tamang (Western and Eastern dialects), Chantyal, Gurung, Managba, Nar-phu, Seke and Thakali (Eppele et al. 2012)
}

Gipan 4. 2019. 142-161. 
Hari (1969; 1970), Limbu and Limbu (2008) and Gauchan et al. (2065BS). ${ }^{2}$ Hari (1969; 1970) has not taken care of 'murmured' properties in consonants whereas Limbu and Limbu (2008) has neither tried to investigate 'murmured' properties nor the breathiness in vowels in Thakali. Gauchan et al. (2065BS: 23) simply provides an inventory of basic sounds based on Gauchan (2061BS). Magar Kaike (Regmi 2013), Western Tamang (Regmi and Regmi 2018), Seke (Honda, 2002; 2003) and Manange (Hildebrandt, 2004; 2005) provide a detailed phonological analysis. There exist some description of phonology in Ghale (Pudel 2008; Khadki 2010), Chantyal (Noonan 2003a), Nar-Phu (Noonan 2003b), Tamang (Mazaudon 2003) and Gurung (Glover 1970; 1974). Thakali is one of the members of the Gurungic cluster of West Bodish sub-section of the Bodish section of Bodic branch of Tibeto-Burman language family (Eppele et al. 2012). Figure 1 presents the position of Thakali among the languages of West Bodish sub-section (based on Bradley 2002).

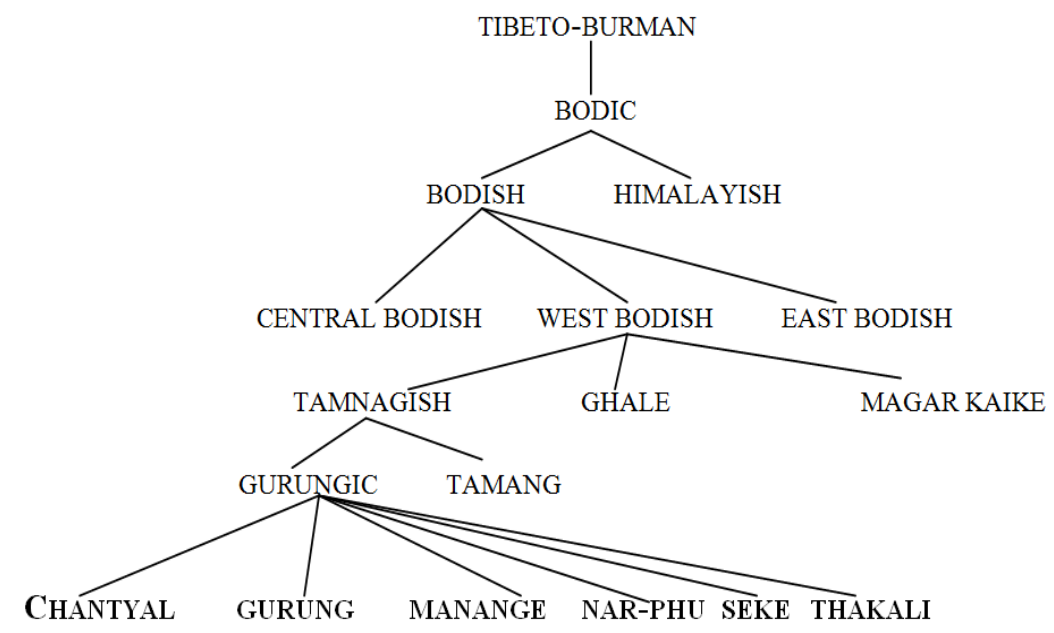

Figure 1: The position of Thakali among the languages of West Bodish sub-section

Till the date, no attempt has been made to compare the segmental phonological properties of Thakali with the common segmental phonological properties of Bodish section as well as with those properties of the languages of West Bodish sub-section from a typological perspective. This study based on both primary and secondary data has employed a functional perspective developed in Symons (1993) in identifying the segmental phonological properties in Thakali. The secondary data in Thakali have been heavily gleaned from Gauchan (2061BS) and Tulachan (2069BS).

\footnotetext{
${ }^{2}$ Georg (1996) offers some description of phonology in Thakali. However, it is about a dialect of Thakali referred to as Marpha Thakali.
} 
144 / Segmental phonological proporties...

This paper is organized into six sections. Section 2 attempts to investigate the properties of consonant phonemes in Thakali. In section 3, we look at properties of the vowels in the language. Section 4, briefly, deals with syllable structure in Thakali. In section 5, we compare the segmental properties so far investigated in Thakali with Bodish and other West-Bodish languages from a typological perspective. Section 6 summarizes the findings of the paper.

\section{Properties of consonant phonemes}

This section sets up an inventory of consonant phonemes with their phonological oppositions and deals with the distribution of consonants as well as consonant clusters in Thakali.

\subsection{Segmental consonant phonemes}

Hari (1970: 258-278) establishes 21 consonant phonemes in Thakali. They include twelve obstruants [viz., $\mathrm{p}, \mathrm{t}, \mathrm{t}, \mathrm{ts}, \mathrm{k}, \mathrm{p}^{\mathrm{h}}, \mathrm{t}^{\mathrm{h}}, \mathrm{t}^{\mathrm{h}}, \mathrm{ts}^{\mathrm{h}}, \mathrm{k}^{\mathrm{h}}, \mathrm{s}$, and $\mathrm{h}$ ] and nine sonants ( viz., $\mathrm{m}$, $\mathrm{n}, \mathrm{y}, 1, \mathrm{1}, \mathrm{r}, \underset{\mathrm{r}}{\mathrm{r}}, \mathrm{w}, \mathrm{j}]$. Limbu and Limbu (2008: 33-47), a preliminary study, presents only nineteen consonants unlike Hari (1970). ${ }^{3}$ Gauchan et al. (2065: 23) has listed 34 consonants in Thakali. ${ }^{4}$ Based upon the minimal pairs, Thakali exhibits a set of 33 segmental consonant phonemes. Table 1 presents segmental consonant phonemes in Thakali (In the transcription used here, $<\mathrm{h}>$ indicates aspiration, $<\mathrm{h}>$ murmur).

Table 1: Segmental consonant phonemes in Thakali

\begin{tabular}{|c|c|c|c|c|c|c|c|}
\hline MANNER $\quad$ OF & \multicolumn{7}{|c|}{ PLACES OF ARTICULATION } \\
\hline Stops & Labial & Dental & Alveolar & Palatal & Retroflex & Velar & Glottal \\
\hline Unaspirated & $\mathrm{p}$ & $\mathrm{t}$ & & & $t$ & $\mathrm{k}$ & \\
\hline Aspirated & $\mathrm{ph}$ & th & & & th & $\mathrm{kh}$ & \\
\hline $\begin{array}{l}\text { Murmured stop with } \\
\text { voiceless onset }\end{array}$ & ph & th & & & th & kf & \\
\hline Nasals & & & & & & & \\
\hline Voiced & $\mathrm{m}$ & & $\mathrm{n}$ & & & $\eta$ & \\
\hline Murmured & $\mathrm{mh}$ & & nh & & & yh & \\
\hline Affricates & & & & & & & \\
\hline Unaspirated & & & ts & & & & \\
\hline Aspirated & & & tsh & & & & \\
\hline $\begin{array}{l}\text { Murmured affricate } \\
\text { with voiceless onset }\end{array}$ & & & tsh & & & & \\
\hline Fricatives & & & & & & & \\
\hline Voiceless & & & $\mathrm{s}$ & & & & h \\
\hline $\begin{array}{l}\text { Murmured fricative } \\
\text { with voiceless onset }\end{array}$ & & & sh & & & & \\
\hline
\end{tabular}

${ }^{3}$ Georg (1996: 33) has established 19 consonants for Marpha Thakali.

${ }^{4}$ Minimal pair for labial murmured approximant /wh/ has not yet been established. 
Regmi and Regmi / 145

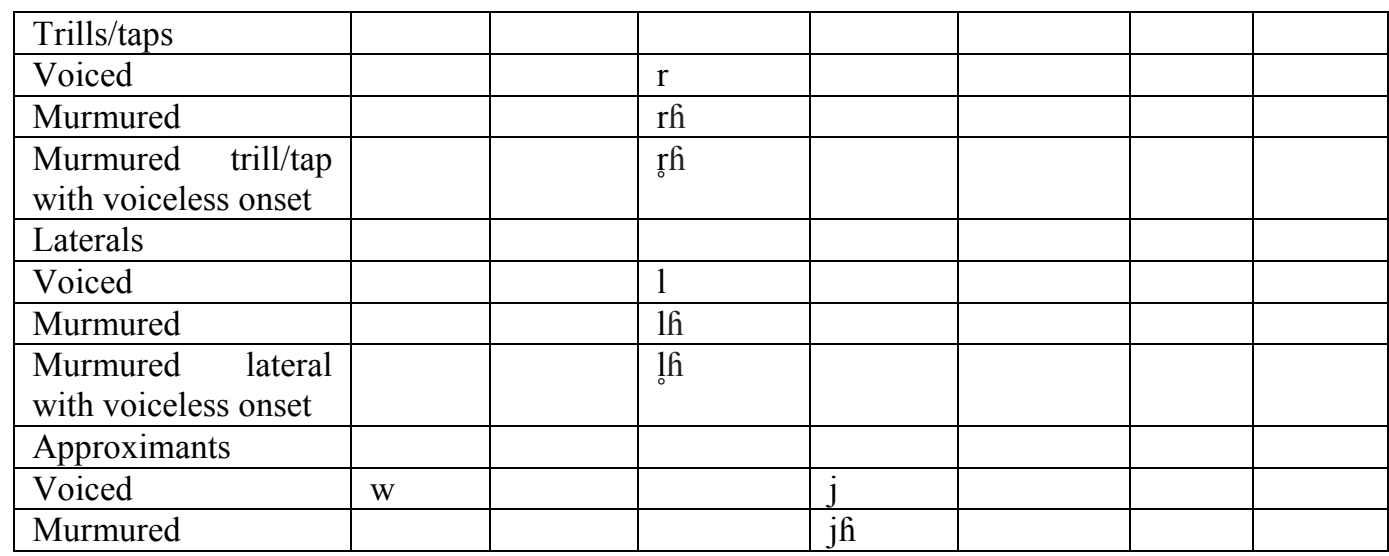

Table 1 presents contrasts in seven points/places of articulation in Thakali. They include labial, dental, alveolar, palatal, retroflex, velar and glottal. In terms of manner of articulation, there are seven types of consonant phonemes in Thakali. They include stops, nasals, affricates, fricatives, trills, laterals and approximants. Thakali presents contrasts involving voice onset time and murmur. Such contrasts are attested in stops, affricates, fricatives, trills/taps and laterals in Thakali. In terms of voicing, there are two types of consonant phonemes: voiceless and voiced whereas in terms of aspiration there are two types of consonant phonemes in Thakali: aspirated and unaspirated. Besides, Thakali contrasts voiced murmured and voiceless murmured in trills/taps and laterals. Thus, Thakali contains voiceless unaspirated, voiceless aspirated, voiced murmured and voiceless murmured (murmured sound with voiceless onset). ${ }^{5}$

2.2 Phonological oppositions ${ }^{6}$

\subsubsection{Labial stops}

Thakali has three labial stops:/p/, /ph / and /ph/. It lacks voiced labial stops. The phoneme $/ \mathrm{p} /$ is a voiceless labial unaspirated stop whereas $/ \mathrm{ph} /$ is a labial murmured stop with voiceless onset. The phoneme $/ \mathrm{ph} /$ is a voiceless labial aspirated stop. They present phonological opposition in terms of aspiration and murmur only in word-initial position as in (1).

(1) Labial stops: /p/,/ph/, /ph/

/po/ 'flood'

/pho/ 'dough'

/pho/ 'deer'

5 In Thakali, "murmured ... with voiceless onset" may possibly be interpreted as voiceless consonant followed by breathy voice vowel or murmur vowel.

${ }^{6}$ Most of the phonological oppositions are built on data gleaned from Gauchan (2061BS) and Hari (1970). 
146 / Segmental phonological proporties...

\subsubsection{Dental stops}

There are three dental stops in Thakali: /t/, /th / and /th/. The phoneme /t/ is a voiceless dental unaspirated stop whereas /th/ is a dental murmured stop with voiceless onset. The phoneme $/ \mathrm{th} /$ is a voiceless dental aspirated stop. They show phonological contrast in terms of aspiration and murmur in word-initial position only as in (2).

(2) Dental stops: /t/, /th /, / th $/$

/ta/ 'what'

/tha/ 'now'

/tha/ 'plank'

\subsubsection{Retroflex stops}

There are three retroflex stops in Thakali: $/ \mathrm{t} /, / \mathrm{th} /$ and $/ \mathrm{th} /$. The phoneme $/ \mathrm{t} /$ is a voiceless retroflex unaspirated stop whereas $/ \mathrm{th} /$ is a retroflex murmured stop with voiceless onset. The phoneme $/ \mathrm{th} /$ is a voiceless retroflex aspirated stop. They show phonological contrast in word-initial position only as the labial and dental stops as in (3).

(3) Velar stops: /t/, /th/, /th/

/to/ 'head'

/tho/ 'enemy'

/tho/ 'hawk'

\subsubsection{Velar stops}

There are three velar stops in Thakali: $/ \mathrm{k} /, \mathrm{kh} /$, and $/ \mathrm{kh} /$. The phoneme $/ \mathrm{k} /$ is a voiceless velar unaspirated stop whereas $/ \mathrm{kh} /$ is a velar murmured stop with voiceless onset. The phoneme $/ \mathrm{kh} /$ is a voiceless velar aspirated stop. They show phonological contrast in terms of aspiration and murmur in word-initial position only as labial and dental stops as in (4).

(4) Velar stops: $/ \mathrm{k} /, / \mathrm{kh} /$ and $/ \mathrm{kh} /$

/kə/ 'knowledge'

/khə/ 'saddle'

/khə/ 'hem'

\subsubsection{Nasals}

There are three clear nasals in Thakali: $/ \mathrm{m} /, / \mathrm{n} /$ and $/ \mathrm{y} /$ and three murmured nasals: $/ \mathrm{mh} /$, $/ \mathrm{nh} /$ and $/ \mathrm{yh} /$. The phoneme $/ \mathrm{m} /$ is a bilabial nasal whereas $/ \mathrm{n} /$ is an alveolar nasal. The phoneme $/ \mathrm{y} /$ is a velar nasal. The phoneme $/ \mathrm{mh} /$ is a bilabial murmured nasal whereas $/ \mathrm{nh} /$ is a murmured alveolar nasal. The phoneme $/ \mathrm{nh} /$ is a murmured velar nasal. The clear nasals show phonological oppositions among themselves as well as with their murmured counterparts. Such oppositions occur in word-initial positions only as in (5).

(5) a. Nasals: /m/, /n/, /y/

/mo/ 'a type of cane'

/nə/ 'nose'

/yə/ 'first person singular' 
b. $/ \mathrm{m} /, / \mathrm{mh} / ; / \mathrm{n} /, / \mathrm{nh} / ; / \mathrm{n} /, / \mathrm{nh} /$

/mal 'a kind of cane'

lmhal 'garden'

/no/ 'nose'

/nfia/ 'ear'

/yə/ 'first person singular'

/yho/ 'shaman's drum'

\subsubsection{Alveolar affricates}

There are three alveolar africates in Thakali: /ts/, /tsh/, and /tsh/. The phoneme /ts/ is a voiceless alveolar unaspirated affricate whereas $/ \mathrm{tsh} /$ is a voiceless alveolar aspirated affricate. The segment /tsh/ is a murmured alveolar affricate with voiceless onset. They show phonological contrast in terms of aspiration and murmur in word-initial position only as in (6).

(6) Alveolar affricates:/ts/, /tsh/, /tsh/

/tsa/ 'wrist'

/tsha/ 'cremation ground'

/tshal 'son'

\subsubsection{Fricatives}

There are three fricatives in Thakali: /s/, /sh/ and /h/. The segment/s/, a voiceless alveolar fricative, shows phonological contrast with /sh /, a murmured alveolar fricative with voiceless onset and / $\mathrm{h} / \mathrm{a}$ voiced glottal fricative, in word-initial position as in (7).

(7) Fricatives: /s/, /sh /, /h/

/ser/ 'east'

/her/ 'butter dabbed on the rim of alcohol-filled glass'

/sawal 'complete'

/shawa/ 'good'

\subsubsection{Liquids (laterals and trills)}

The alveolar lateral segment / / shows the phonological opposition with alveolar trill $/ \mathrm{r} /$ in word-initial position only as in (8).

(8) Lateral and trill: /1/, /r/

lla/ 'month'

lral 'goat'

The unaspirated lateral /1/ presents oppositions with the murmured lateral / $/ \mathrm{h} /$ and the murmured lateral with voiceless onset $/ 1 \mathrm{~h} /$. Such oppositions occur only in the wordinitial position as in (9).

(9) Laterals: /1/, /lh/, /li /

lla/ 'month'

llha/ 'tallied score in an archery competition'

llhal 'god' 
148 / Segmental phonological proporties...

The unaspirated trill /r/ presents oppositions with the murmured trill $/ \mathrm{rh} /$ and the murmured lateral with voiceless onset $/ \mathrm{rh} /$. Such oppositions occur only in the wordinitial position as in (10).

(10) Trills: /r/, /rh/, / rih /

$\begin{array}{ll}\text { /re-wal } & \text { 'to wake up' } \\ \text { /rhe-wa/ } & \text { 'to hope' } \\ \text { /rhe-wal } & \text { 'to harvest' }\end{array}$

\subsubsection{Approximants}

The bilabial approximant /w/ shows the phonological contrast with palatal approximant /j/ only in word-initial position as in (11).

(11) Approximants: /w/, /j/

/-wa/ 'nominalizer'

/ja/ 'high mountain'

The clear palatal approximant /j/ shows the phonological contrast with the murmured palatal approximant $/ \mathrm{jh} / \mathrm{as}$ in (12).

(12) Approximants: $/ \mathrm{j} /, / \mathrm{jh} /$

ljo-wal 'enough'

/jho-wa/ 'to sieve beer'

\subsection{Distribution of segmental consonants}

Thakali presents the distribution of segmental consonants in different positions: word initial, intervocalic and word final. Table 2 presents the positional distribution of consonants in Thakali.

Table 2: Positional distribution of segmental consonants in Thakali

\begin{tabular}{|c|c|c|c|c|c|c|}
\hline & \multicolumn{2}{|l|}{ \#- } & \multicolumn{2}{|l|}{$v-v$} & \multicolumn{2}{|l|}{-\# } \\
\hline $\mathrm{p}$ & /pər-wə/ & 'to add' & /khepa/ & 'old, aged' & /chəp/ & 'basket' \\
\hline $\mathrm{ph}$ & /phə/ & 'husband' & /aphi/ & 'mother's elder sister' & - & - \\
\hline ph & /phom/ & 'shoulder' & - & - & - & - \\
\hline $\mathrm{t}$ & $/ \mathrm{ta} /$ & 'horse' & /kyutu/ & 'progress' & & \\
\hline th & /thəmpə/ & 'to keep' & - & - & - & - \\
\hline th & /thəm / & 'tradition' & - & - & - & - \\
\hline$t$ & $/ \mathrm{ta} /$ & 'head, & /thotok/ & 'pride' & /pet/ & 'grain* \\
\hline th & /tha/ & 'hawk' & - & - & - & - \\
\hline the & /tha/ & 'enemy' & /khəthi/ & 'glacier' & - & - \\
\hline ts & /tsa/ & 'wrist' & /hetsen/ & 'leopard' & - & - \\
\hline tsh & /tshə/ & $\begin{array}{l}\text { 'cremation } \\
\text { ground' }\end{array}$ & - & - & - & - \\
\hline tsh & tsfiə & 'son' & - & - & - & - \\
\hline $\mathrm{r}$ & /ro/ & 'goat' & /karu/ & 'oat' & /mfiər/ & 'gold' \\
\hline rh & /rfio/ & 'friend' & - & - & - & - \\
\hline rhh & /rife/ & 'lace' & - & - & - & - \\
\hline 1 & $/ \mathrm{l} /$ & 'month' & /khulu/ & 'soft wool' & /khul/ & 'mystery' \\
\hline
\end{tabular}


Regmi and Regmi / 149

\begin{tabular}{|c|c|c|c|c|c|c|}
\hline 1h & /lfie/ & 'destiny' & - & - & - & - \\
\hline lih & /16ə/ & 'god' & - & - & - & - \\
\hline $\mathrm{m}$ & $/ \mathrm{m} ə \mathrm{n} /$ & 'medicine' & /kfoma/ & 'pheasant' & /khum/ & 'kidney' \\
\hline $\mathrm{n}$ & /no/ & 'nose' & /tseno/ & 'seive' & /mən/ & 'medicine' \\
\hline $\mathrm{y}$ & /yər/ & 'upright' & /tsuni/ & 'twelve' & /wəy/ & 'blessing' \\
\hline $\mathrm{mh}$ & /mfiər/ & 'gold, butter' & - & - & - & - \\
\hline nh & /nfiə/ & 'ear' & & - & - & - \\
\hline jh & /yfi/ & 'drum' & & - & - & - \\
\hline $\mathrm{S}$ & /sa/ & 'tooth' & /kosa/ & 'pud' & /ches/ & 'respect' \\
\hline sh & /she-wə/ & 'to endure' & - & - & - & - \\
\hline h & /hecen/ & 'leopard' & - & - & - & - \\
\hline $\mathrm{j}$ & $/ \mathrm{ja} /$ & 'hand' & /kəyer/ & 'cup' & - & - \\
\hline jh & /jfien-wə/ & 'to stare' & & & - & - \\
\hline $\mathrm{W}$ & /wəy/ & 'blessing' & /kəwə/ & 'thick' & - & - \\
\hline $\mathrm{k}$ & /kyu / & 'water' & /tsika/ & 'barley' & /thuk/ & 'vulture' \\
\hline $\mathrm{kh}$ & /khum/ & 'kidney' & /akhe/ & 'grandfather' & - & - \\
\hline kh & /kfirsə / & 'knife' & - & - & - & - \\
\hline
\end{tabular}

* grain taken from the landlord in exchange of manure of the sheep farm

Some generalizations regarding to the distribution of the segmental consonants in the Thakali may be made from the examples given in Table 2. They are as follows:

a) All the consonant phonemes occur in the word-initial position;

b) The consonant segments $/ \mathrm{p} /, / \mathrm{t} /, / \mathrm{r} /, / 1 /, / \mathrm{m} /, / \mathrm{n} /, / \mathrm{y} /, / \mathrm{s} /$ and $/ \mathrm{k} /$ occur in all positions: word initial, inter-vocalic and word final;

c) The segments $/ \mathrm{ph} /, / \mathrm{t} /, / \mathrm{th} /, / \mathrm{ts} /, / \mathrm{j} /, / \mathrm{w} /$ and $/ \mathrm{kh} /$ occur in intervocalic positions in Thakali; and

d) Murmured consonants, except $/ \mathrm{th} /$ are generally restricted to morpheme initial position.

\subsection{Consonant clusters}

Thakali presents consonant clusters which are exclusively realized within the syllable only in syllable initial position. ${ }^{7}$ Hari (1970: 126-28) reports that only the segments /p/, $/ \mathrm{ph} /, / \mathrm{m} /, / \mathrm{ts} /, / \mathrm{tsh} /, / \mathrm{k} /, / \mathrm{kh} /, / \mathrm{s} /, / \mathrm{y} /$ and $/ \mathrm{t} / \mathrm{participate}$ as the first $\mathrm{C}$ (consonant) and the segments $/ \mathrm{r} /, / 1 /, / \mathrm{j} /$ and $/ \mathrm{w} /$ may partake as the second $\mathrm{C}$ for the syllable initial CCclusters in Thakali. Unlike in Hari (1970), murmured segments, viz., /ph/, /kh/, /tsh/, /th/, /lh/,/sh/, /yh/and /h/ can also partake as $\mathrm{C}_{1}$ ( i.e., first C) in Thakali. In Thakali, $\mathrm{C}_{1}$ consists exclusively of stops (except $/ \mathrm{th} /$, /th/ and $/ \mathrm{t} /$,), nasals (except $/ \mathrm{n} /$ and $/ \mathrm{mh} /$ ), affricates, fricatives, laterals (except $/ 1 /$ and $/ 1 \mathrm{~h} /$ ) and taps (except $/ \mathrm{rh} /$ and $/ \mathrm{rh} /$ ) whereas as $\mathrm{C}_{2}$ exclusively consists of clear trill, lateral (clear and murmured) and labial and palatal approximants. Table 3 presents the patterns of consonant clusters in Thakali.

${ }^{7}$ Consonant clusters are found only in root-initial position in the Tibeto-Burman languages (Benedict 1972; Matisoff 2003). 
150 / Segmental phonological proporties...

Table 3: Patterns of consonant clusters in Thakali

\begin{tabular}{|c|c|c|c|c|c|}
\hline \multirow[b]{2}{*}{$\mathrm{C}_{1}$} & \multicolumn{5}{|c|}{$\mathrm{C}_{2}$} \\
\hline & $\mathrm{r}$ & 1 & lif & $\bar{j}$ & $\mathrm{~W}$ \\
\hline $\mathrm{p}$ & + & + & + & + & + \\
\hline $\mathrm{ph}$ & - & - & & + & \\
\hline ph & + & - & & + & \\
\hline $\mathrm{k}$ & + & + & & + & \\
\hline $\mathrm{kh}$ & + & + & & + & \\
\hline kh & - & - & & + & \\
\hline $\mathrm{m}$ & + & - & + & + & \\
\hline ts & - & - & - & + & \\
\hline tsh & - & - & - & + & \\
\hline tsh & - & - & - & + & \\
\hline $\mathrm{t}$ & - & - & - & + & \\
\hline th & + & - & - & + & \\
\hline $\mathrm{r}$ & - & - & - & + & \\
\hline lh & - & - & - & + & \\
\hline $\mathrm{S}$ & - & - & - & + & \\
\hline sh & - & - & - & + & \\
\hline $\mathrm{y}$ & - & - & - & + & \\
\hline ph & - & - & - & + & \\
\hline h & - & - & - & + & \\
\hline
\end{tabular}

Table 3 shows that the consonant clusters in Thakali are found only in the root-initial (i.e., onset) positions. This is a common feature of the Tibeto-Burman languages. The consonant clusters in Thakali may be discussed as follows:

\subsubsection{Stop and palatal approximant}

The stops /p/,/ph/, /ph/, /t/, /th/, /k/, /kh/ and / kh /as $\mathrm{C}_{1}$ can combine with the palatal approximant $/ \mathrm{j} /$ as $\mathrm{C}_{2}$ as in (13).
(13) a. pj /pjan-wə/
'clever'
b. phj /phja/
'broom'
c. $p h j / \mathrm{phja} /$
'hoof'
d. $t j$ /tjutumtsuəm/
'at one stroke'
e. thj /thjolə-wə/
'to consult in private'
f. $k j \quad / \mathrm{kju} /$
'water'
g. khj/khjə/
'spoon'
h. khj /khjo-wə/
'to scoop and offer cooked rice'

\subsubsection{Stop and lateral}

The stop /p/ as $\mathrm{C}_{1}$ can combine with the clear /1/ and murmured lateral $/ \mathrm{ph} /$ as $\mathrm{C}_{2}$ as in (14).

(14) $\mathrm{pl} /$ pləwə/ 'to mutter in sleep'

pl /pla/ 'curry'

plh /plhu/ 'seed' 


\subsubsection{Stop and trill}

The stops $/ \mathrm{p} /, / \mathrm{ph} /$ and $/ \mathrm{th} /$ as $\mathrm{C}_{1}$ can combine with the clear trill $/ \mathrm{r} /$ as $\mathrm{C}_{2}$ as in (15).

$\begin{array}{lll}\text { (15) } p r & / \text { prop-pa/ } & \text { 'to toast bread' } \\ p h r & / \text { phri/ } & \text { 'root' } \\ p h r & / \text { phro/ } & \text { 'smallpox' } \\ t h r & / \text { thru-wa/ } & \text { 'to compare' }\end{array}$

\subsubsection{Stop and bilabial approximant}

The stops $/ \mathrm{p} /$ as $\mathrm{C}_{1}$ can combine with the clear bilabial approximant $/ \mathrm{w} /$ as $\mathrm{C}_{2}$ as in (16) (16) $p w \quad / p w a / \quad$ 'exclamation of surprise'

\subsubsection{Affricates and palatal approximant}

The affricate segments $/ \mathrm{ts} / \mathrm{tsh} /$ and $/ \mathrm{tsh} /$ in $\mathrm{C}_{1}$ position can combine with palatal approximant $/ \mathrm{j} /$ as $\mathrm{C}_{2}$ as in (17).
(17) $t s j \quad / t s j u /$ 'energy'
tshj /tshjuku/ 'oil'
tshj /tshja/ 'bird'

2.4.6 Nasals and palatal approximant

The nasals, $/ \mathrm{m} /, / \mathrm{y} /$ and $/ \mathrm{yh} /$ as $\mathrm{C}_{1}$ position can combine with palatal approximant, $/ \mathrm{j} /$ as $\mathrm{C}_{2}$ as in (18).

$$
\begin{array}{lll}
\text { (18) } m j & / \mathrm{mja} / & \text { 'mole' } \\
\eta j & / \mathrm{nja} / & \text { 'semen' } \\
\eta h^{\prime} j & / \text { yfjo-wə/ } & \text { 'to look' }
\end{array}
$$

\subsubsection{Bilabial nasals and trill and liquid}

The bilabial nasal $/ \mathrm{m} /$ as $\mathrm{C}_{1}$ position can combine with trill and murmured lateral as $\mathrm{C}_{2}$ as in (19).

$$
\begin{array}{lll}
\text { (19) } \mathrm{mr} & / \mathrm{mra} / & \text { 'weeds' } \\
\mathrm{mlh} & / \mathrm{mlha} / & \text { 'uncooked rice' }
\end{array}
$$

\subsubsection{Fricative and palatal approximant}

The fricatives $/ \mathrm{s} /, / \mathrm{sh} /$ and $/ \mathrm{h} /$ as $\mathrm{C}_{1}$, can combine with the palatal approximant, $/ \mathrm{j} /$ as $\mathrm{C}_{2}$ as in $(20)$.

$\begin{array}{lll}\text { (20) } s j & / \text { sja/ } & \text { 'meat' } \\ \text { shj } & \text { /shjay/ } & \text { 'vomit' } \\ \text { hj } & \text { /hja/ } & \text { 'bull yak' }\end{array}$

\section{Segmental vowel phonemes}

Hari (1970: 272) presents a set of six vowel phonemes and their breathy (also called murmured voice) counterparts in Thakali. However, Limbu and Limbu (2008: 33) does not take account of murmured voice (i.e., breathy) counterparts. Unlike Western Tamang (Regmi and Regmi 2018), Thakali lacks the contrastive length. The distinctive nasalized 
152 / Segmental phonological proporties...

vowels, which are the characteristics of the Bodish group of the Tibeto-Burman languages (Noonan 2003:6) are absent in Thakali. However, nasalized variants occur following nasal consonants (Hari 1970: 273) as in (21)
(21) a. Imel [mẽ] 'fire'
b. Ima/ [mã] 'down'
c. $/ m a /$ [mạ̃] 'son-in-law'
d. $/ m u /$ [mũ] 'sky'
e. $/ \mathrm{mom} /$ [mõm] 'grandmother'
f. $/ m o /$ [mọ̃ $\quad$ 'cloud'

In this section, we briefly deal with oral monophthongs, their phonological oppositions, their distributions as well as diphthongs in Thakali.

\subsection{Oral monophthongs}

Thakali contains six vowels with their murmured voice (i.e., breathy) counterparts. Table 4 presents the inventory of oral monophthongs with their murmured voice (i.e., breathy) counterparts in Thakali.

Table 4: Inventory of oral monophthongs in Thakali

\begin{tabular}{|l|ll|ll|ll|}
\hline & \multicolumn{2}{|l|}{ Front } & Central & \multicolumn{2}{l|}{ Back } \\
\hline High & i & i & & & u & u \\
\hline Mid & e & e & $\partial$ & e & o & o \\
\hline Low & & & a & a & & \\
\hline
\end{tabular}

Table 4 exhibits six monophthongs with their murmured voice (i.e., breathy) counterparts in terms of the height and front-back position of the tongue. They are: /i, i/ high front, /e, è / mid front, /ə ô $/$ mid central, /a, ạ/ low central, /u, ụ/ high back and /o, o / mid back.

\subsection{Phonological oppositions}

The oral monophthongs present the phonological oppositions in terms of height, frontback positions as well as murmur (i.e., breathiness) in Thakali.

a. Height oppositions

Thakali presents the oppositions for the vowels in terms of height as in (22).

(22) a. /i/ vs. /e/

$/ k^{h} i / \quad$ 'credit'

$/ k^{h} e / \quad$ 'incomet'

b. /a/ vs. /a/

$/ k^{h}$ al 'hem'

$/ k^{h} a / \quad$ 'neck'

c. $/ \mathrm{u} / \mathrm{vs} . / \mathrm{o} /$

$/ p u / \quad$ 'clay vessel with a hole'

/po/ 'flood' 
d. i/ vs. /a/

lli/ 'face'

llal 'soul'

e. /e/ vs. /a/

/kel 'farmland'

/ka/ 'blood'

b. Front-back oppositions

Thakali presents the oppositions for the vowels in terms of front-back position as in (23).

(23) a. /i/ vs. /u/

/mi / 'eye'

/mu/ 'sky'

b. /e/ vs. /a/

lmel 'fire'

lma/ 'a kind of cane'

c. /e/ vs. /o/

/pel 'story

/po/ 'flood'

d. /a/ vs. /o/

$/ p^{h} a /$ 'supporting structure at the bottom of a bamboo basket'

$/ p^{h}$ o/ 'deer'

e. /i/ vs. /a/

/mi/ 'eye'

/mal 'a kind of cane'

c. Murmur (i.e., breathiness)

Thakali presents the oppositions for the vowels in terms of murmur (i.e., breathiness) as in (24).

(24) a. /i/ vs. /ị/

ltiwa/ 'to spread'

/tiwal 'to stammer'

b. /e/ vs. /ẹ/

/tewa/ 'to fall'

ltewa 'to drive away'

c. /o/ vs. /o/

ltowal 'to need'

ltowa 'to meet'

d. /a/ vs. /ạ/

/kawal 'thick'

/kạwa/ 'thick' 
154 / Segmental phonological proporties...

e. /a/ vs. /a/

Inal 'take!'

lnal 'pus'

f. $/ \mathrm{u} / \mathrm{vs} . / \mathrm{u} /$

lru/ 'horn'

/rul stir

\subsection{Distribution of oral monophthongs}

Table 5 provides an overview of the positional distribution of the oral monophthongs with their murmured voice (i.e., breathy) counterparts in Thakali.

Table 5: Distribution of oral monophthongs in Thakali

\begin{tabular}{|l|l|l|l|}
\hline Monophthongs & Word initial & Word medial & Word final \\
\hline i & + & + & + \\
\hline$\underline{i}$ & + & - & - \\
\hline e & + & + & + \\
\hline e & + & - & - \\
\hline a & + & + & + \\
\hline$a$ & + & - & - \\
\hline a & + & + & + \\
\hline$a$ & + & - & - \\
\hline o & + & + & + \\
\hline$o$ & + & - & - \\
\hline$u$ & + & + & + \\
\hline$u$ & + & - & - \\
\hline
\end{tabular}

Table 5 shows that the clear monophthongs can occur in all positions: word-initially, word-medially and word-finally. However, murmured voice (i.e., breathy) ones can occur only word-initially. Table 6 presents the positional distribution of the oral monophthongs with examples in Thakali.

Table 6: Positional distribution of the oral monophthongs in Thakali

\begin{tabular}{|c|c|c|c|c|c|c|}
\hline & Word initial & & Word medial & & Word final & \\
\hline i & /intuy/ & 'horse's bell' & /limpo/ & 'sweet' & $/ \mathrm{mi} /$ & 'eye' \\
\hline i & /inwa/ & 'to be' & - & - & - & - \\
\hline $\mathrm{e}$ & /ewa/ & 'to return' & $/ \mathrm{ken} /$ & 'father-in-law' & $/ \mathrm{me} /$ & 'fire' \\
\hline e & /ensewa/ & 'to praise' & - & - & - & - \\
\hline$\partial$ & /opta/ & 'decision' & /kən/ & 'rice' & & \\
\hline 2 & /ə̣hjər/ & 'thousand' & - & - & - & - \\
\hline $\mathrm{a}$ & /ana/ & 'elder sister' & $/ \mathrm{kay} /$ & 'shoulder' & $/ \mathrm{ka} /$ & 'blood' \\
\hline ạ & /ạkhwə/ & 'to sulk' & - & - & - & - \\
\hline o & /onwa/ & 'to show' & /kon/ & 'cloth' & $/ \mathrm{ro} /$ & 'fruits' \\
\hline 0 & /oplawa/ & 'to winnow' & - & - & - & - \\
\hline $\mathrm{u}$ & /umpo/ & 'to pour' & /kum/ & 'urine' & $/ \mathrm{ru} /$ & 'horn' \\
\hline$\underline{u}$ & /ụkpa/ & 'owl' & - & - & - & - \\
\hline
\end{tabular}




\subsection{Diphthongs}

There are six diphthongs in Thakali. They are: əi, ui, oi, ai, ou and oe. The mid-central vowel /ə/ makes a cluster with high front vowel /i/ and high back vowel/u/. The mid-back vowel /o/ clusters with the high front vowel /i/ and the mid-front vowel /e/. Similarly, the high back vowel $/ \mathrm{u} /$ goes for clustering with the high-front vowel/i/ and low-back vowel/a/ clusters with the high-front vowel/i/ in Thakali. Following are the examples:

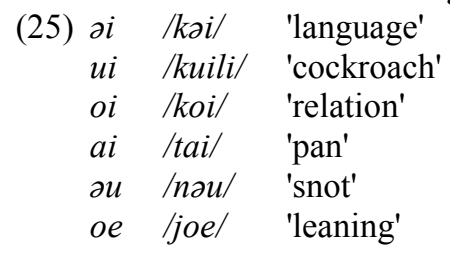

4. Syllable structure

This section deals with syllable patterns, the syllable weight and the complex onset in Thakali.

\subsection{Syllable patterns}

Hari (1970: 125-142) has identified two kinds of contrasts in tone in Thakali: contrast for breathiness (tense vs. lax)) and contrasts for pitch contour. Thus, assuming Thakali as a tonal language, the canonical structure of the syllable at the maximum may be presented as in $(26){ }^{8}$

(26) $(\mathrm{T})\left(\mathrm{C}_{\mathrm{i}}\right)(\mathrm{X}) \mathrm{V}\left(\mathrm{C}_{\mathrm{f}}\right)$

The canonical structure of the syllable in Thakali shows that $\mathrm{V}$ (i.e., nucleus) is obligatory. The other constituents, ( $\mathrm{T}$, tone), $\left(\mathrm{C}_{\mathrm{i}}\right.$, initial consonant), (X, glide or liquid), and $\left(\mathrm{C}_{\mathrm{f}}\right.$, final consonant) are optional. ${ }^{9}$ Thakali admits only six types of syllable patterns as in (27).

(27) a. V /ale/ 'younger brother'

b. $\mathrm{vC} / \mathrm{ur} / \mathrm{\text {'yellow' }}$

c. $\mathrm{CV} / \mathrm{tsu} / \mathrm{min} / \mathrm{his}$

d. $\mathrm{CVC} / \mathrm{min} /$ 'name'

e. CXV $/ \mathrm{kra} / \quad$ 'head'

f. CXVC /mlay/ 'black'

The syllable structure at the maximum as in (27f) consists of (C) (X) V (C). Figure 2 presents formally the maximum canonical structure of the syllable in Thakali.

\footnotetext{
${ }^{8}$ At present, tone, a suprasegmental property, may be debatable in Thakali. Tulachan (2069BS) argues that presence of murmur in stops is caused by the loss of tone. Data suggests that Thakali still contains tones as in Tamang.

${ }^{9}$ Mazaudon (2003:293) suggests the canonical form of the syllable in Risiangku Tamang as : (Tone) (Initial Consonant) ( Liquid) ( Semi-vowel) Vowel (Final Consonant).
} 
156 / Segmental phonological proporties...

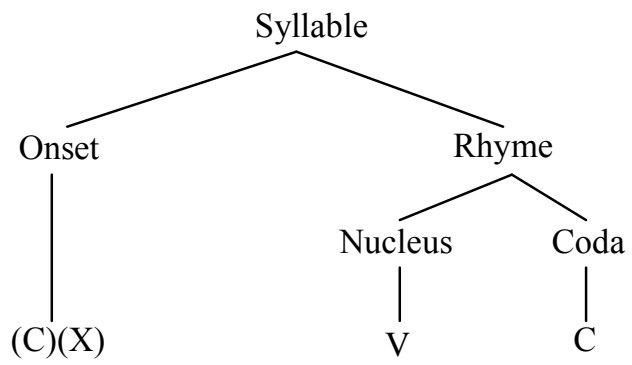

Figure 2: Maximum canonical structure of the syllable in Thakali

\subsection{Syllable weight}

The weight of the syllable is solely determined by the rhyme of the syllable. There are two types of syllables in terms of weight in Thakali: heavy and light. A heavy syllable has the rhyme consisting of VC. Most of the monosyllabic words in Thakali are heavy syllabic as in (28).

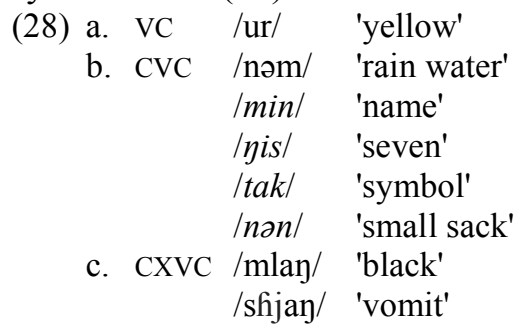

Thakali exhibits light syllables in which the rhyme consists of only nucleus as in (29).

(29) a. V /u/ 'cave'

b. VC /um/ 'mane of the horse'

c. $\mathrm{CV} / \mathrm{ka} /$ 'blood'

$/ \mathrm{ku} / \quad$ 'chest'

\subsection{Complex onset}

Thakali registers only one type of complex onset consisting of CX as in (30).

(30) a. /mja/ 'mole'

b. /nja/ 'semen'

c. /tsju/ 'energy'

d. /pləwə/ 'to mutter in sleep'

e. /pla/ 'curry'

f. /phri/ 'root'

g. /phro/ 'smallpox'

5. Comparison from typological perspective

While making a comparison of segmental phonological properties of Thakali with the common segmental phonological properties of Bodish section and with those properties 
in the languages of West Bodish languages, some typologically interesting properties have been revealed. They are briefly discussed as follows:

\subsection{Segmental phonological properties of Thakali and Bodish}

Languages of Bodish section contain some common segmental properties. They include absence of phonemic voicing contrasts, 2-or-4 way tonal contrast, murmur concomitant with tone, voicing opposition in liquids and/or nasals, retroflex series, distinct alveolar and palato-alveolar series of fricatives, distinct alveolar and palato-alveolar series of affricates, phonemic nasalized vowels, word-initial $/ \mathrm{y} /$ and relatively weak, word boundary stress (Noonan 2003c). Thakali conforms to the most of such phonological properties of Bodish. However, Thakali lacks phonemic voicing contrasts. Nasalized vowels are phonemic and velar voiced nasals take place word initially as in Bodish. Unlike Bodish, it lacks phonemic nasalized vowels. Hari (1970) has identified tone in Thakali. There is voicing oppositions in liquids. However, such oppositions take place in murmured trills and laterals. The murmured may be taken as associated with tone. There are distinct alveolar fricatives and affricates in Thakali. Thakali distinctively presents contrasts for murmured stop with voiceless onset, murmured affricate with voiceless onset, murmured fricative with voiceless onset, murmured trill/tap with voiceless onset and murmured lateral with voiceless onset. This is indeed a striking feature of phonology in Thakali.

\subsection{Segmental phonological properties of Thakali and West-Bodish languages}

Thakali as a member of West Bodish shares a number of phonological properties with other West-Bodish languages. However, it differs from such languages with a rich inventory of consonant segments which contrast involving voice onset time and murmur.

\subsubsection{Segmental consonant properties}

Thakali, like Chantyal (Noonan 2003a: 316), presents contrasts involving voice onset time and murmur. ${ }^{10}$ Such contrasts are attested in stops, affricates, fricatives, trills/taps and laterals in Thakali. Like Chantyal, Thakali contrasts voiceless, voiceless aspirated and murmured stops. Unlike Chantyal, Thakali lacks voiced stops (both voiced and murmured). Nar-Phu (Noonan 2003b: 338) exhibits a set of 25 segmental consonant phonemes. Unlike Chantyal and Thakali, it lacks the contrast between aspirated/voiced and murmured. Mazaudon (2003: 291-92) has indentified 28 consonant phonemes in Tamang (Eastern Tamang). Hildebrandt (2005: 6) has indentified 30 consonant phonemes in Manange. Unlike Thakali and Chantyal, Manange lacks contrasts between aspirated/voiced and murmured. Glottal stops, labialized stops (labial and velar), labialized nasals (labial and velar) and retroflex fricative have been identified in Manange. Such consonants are absent in Thakali. Glover $(1970 ; 1974)$ has established a

\footnotetext{
${ }^{10}$ Noonan (2003: 316 ) holds the view that contrasts involving voice onset time and murmur in Chantyal is typical of the South Asian speech area.
} 
158 / Segmental phonological proporties...

set of 24 segmental consonant phonemes in Gurung. Like Manange, Gurung also lacks contrasts between aspirated/voiced and murmured. Both Magar Kaike (Regmi 2013) and Western Tamang (Regmi and Regmi 2018) lack such contrasts as well. Ghale (Paudel 2008: 169) presents 24 segmental consonants. It also lacks contrasts between aspirated/voiced and murmured. However, Khadki (2010) identifies 18 non-modified basic consonant phonemes and reports that any basic consonant may be palatalized. Seke has three dialects: Tangbe, Tetang and Chuksang. Tangbe (Honda 2003: 52) presents 19 initial segmental consonants whereas Tatang and Chusang (Honda 2002:195) presents 20 initial segmental consonants. Unlike Tangbe, Tatang and Chusang exhibit aspirated retroflex stop. All dialects of Seke lack murmured phonemes. Like Thakali and Nar-Phu, they present two series of voiceless liquids. Unlike, Manange, Seke and NarPhu, Thakali lacks glottal stops. Strikingly, Thakali, unlike other West Bodish languages, presents murmured trill/tap with voiceless onset and murmured lateral with voiceless onset.

\subsubsection{Segmental vowel properties}

Manange (Hildebrandt 2005: 13) presents six plain vowel phonemes. There is no length contrast in vowels. Unlike Thakali, it lacks murmured voice (i.e., breathy) counterparts. Ghale (Pudel 2008:170) provides a set of seven vowels. Nar-Phu (Noonan 2003b: 337) exhibits a set of eight segmental vowel phonemes. Mazaudon (2003: 292) has indentified ten oral monophthongs with length contrast in Tamang (Eastern Tamang). Western Tamang (Regmi and Regmi 2018: 16) exhibits ten monophthongs in terms of the height and front-back position of the tongue. It presents contrast in length unlike in Thakali. Magar Kaike (Regmi 2013: 17) presents six oral monophthongs. The vowel length is not contrastive in Magar Kaike. Gurung (Glover 1970; 1974: 229) presents a set of five segmental vowels and their nasalized counterparts. As in Thakali, each of these vowels may be murmured voice (i.e., breathy) . However, it lacks contrast in length. Chantyal (Noonan 2003a: 315-16) exhibits a set of six vowel phonemes and their nasalized counterparts. There is vowel length in Chantyal. However, it is marginal. Marpha Thakali (Georg 1996: 19) exhibits a set of six vowels. Marpha Thakali (Georg 1996: 19) does not exhibit nasalized counterparts either. All three dialects of Seke (Honda 2002: 197) exhibit a set of six vowels. Vowel length is marginal. Manange (Hildebrandt 2005: 18) presents six nasalized counterparts of oral vowel phonemes. Magar Kaike (Regmi 2013: 19)

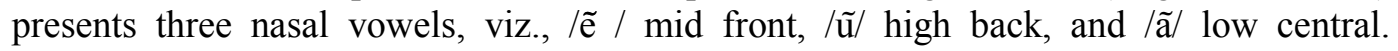
Western Tamang (Regmi and Regmi 2018: 18) exhibits four nasal vowels, viz., high front

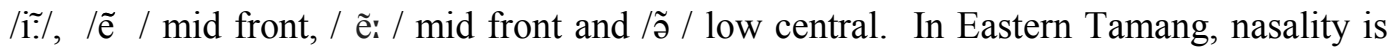
marginally distinctive (Mazaudon 2003: 292).

\subsubsection{Syllable structure properties}

The canonical structure of syllable may be supposed to be consisting of obligatory and optional constituents. V (i.e., nucleus) is obligatory. Optional constituents include ( $\mathrm{T}$, tone $),\left(\mathrm{C}_{\mathrm{i}}\right.$, initial consonant $)$, $(\mathrm{X}$, glide or liquid $)$, and $\left(\mathrm{C}_{\mathrm{f}}\right.$, final consonant). Thakali admits 
only six types of syllable patterns. Such structure bears a resemblance to the structure in Tamang (Eastern and Western). In Western Tamang (Regmi and Regmi 2018: 23) the canonical structure of the syllable consists of $\mathrm{V}$ (i.e., nucleus) and other constituents including ( $\mathrm{T}$, tone $),\left(\mathrm{C}_{\mathrm{i}}\right.$, initial consonant), ( $\mathrm{X}$, glide or liquid), and $\left(\mathrm{C}_{\mathrm{f}}\right.$, final consonant). Western Tamang admits only six types of syllable patterns. Eastern Tamang (Mazaudon 2003: 293) contains a canonical structure of the syllable consisting of $\mathrm{V}$ (i.e., nucleus) and other optional constituents, viz., (tone), (initial consonant), (liquid), (Semi-vowels) vowel and (final consonant). Magar Kaike (Regmi 2013: 24) presents a canonical structure of the syllable consisting of (consonant), (a glide) vowel (a consonant or a vowel). Kaike accepts only five types syllable patterns. Seke (Honda 2002: 194) presents the syllable structure as $\left(C_{1}\right)\left(C_{2}\right) V\left(C_{3}\right)$, where $C_{1}$ is initial consonant, $C_{2}$ is the medial consonant, $\mathrm{V}$ is a vowel and $\mathrm{C}_{3}$ is the final consonant. Manange (Hildebrandt 2004: 27) presents maximal syllable template in Manange being (C) (C) V (C). Thakali has only one complex onset consisting of CX. It is almost attested in all West Bodish languages. Table 7 summarizes the comparison between Thakali and West-Bodish languages in terms of segmental phonological properties.

Table 7: Thakali and West-Bodish languages: A comparison from typological perspective

\begin{tabular}{|c|c|c|c|c|c|c|c|c|c|c|c|}
\hline & \multirow[b]{2}{*}{ Properties } & \multicolumn{10}{|c|}{ West-Bodish Languages } \\
\hline & & $\mathrm{TH}$ & $\mathrm{CH}$ & $\mathrm{MN}$ & WT & ET & NP & KK & GR & $\mathrm{GH}$ & SK \\
\hline 1. & Phonemic voicing contrasts & $\mathrm{x}$ & $\sqrt{ }$ & $\mathrm{x}$ & $\sqrt{ }$ & $\mathrm{x}$ & $\mathrm{x}$ & $\sqrt{ }$ & $\sqrt{ }$ & $\sqrt{ }$ & $\mathrm{x}$ \\
\hline 2. & Retroflex series & $\sqrt{ }$ & $\mathrm{x}$ & $\sqrt{ }$ & $\sqrt{ }$ & $\sqrt{ }$ & $\sqrt{ }$ & $\mathrm{x}$ & $\mathrm{x}$ & $\sqrt{ }$ & $\sqrt{ }$ \\
\hline 3. & Distinct alveolar fricatives & $\sqrt{ }$ & $\sqrt{ }$ & $\sqrt{ }$ & $\sqrt{ }$ & $\sqrt{ }$ & $\sqrt{ }$ & $\sqrt{ }$ & $\sqrt{ }$ & $\sqrt{ }$ & $\sqrt{ }$ \\
\hline 4. & Distinct alveolar affricates & $\sqrt{ }$ & $\sqrt{ }$ & $\sqrt{ }$ & $\sqrt{ }$ & $\sqrt{ }$ & $\sqrt{ }$ & $\sqrt{ }$ & $\sqrt{ }$ & $\sqrt{ }$ & $\sqrt{ }$ \\
\hline 5. & Phonemic nasalized vowels & $\mathrm{x}$ & $\sqrt{ }$ & $\sqrt{ }$ & $\sqrt{ } *$ & $\sqrt{ } *$ & $\sqrt{*}$ & $\sqrt{ } *$ & $\sqrt{ }$ & $* *$ & $\mathrm{x}$ \\
\hline 6. & Voicing opposition in liquids & $\sqrt{ }$ & $\mathrm{x}$ & $\mathrm{x}$ & $\mathrm{x}$ & $\mathrm{x}$ & $\sqrt{ }$ & $\mathrm{x}$ & $\mathrm{x}$ & $\mathrm{x}$ & $\sqrt{ }$ \\
\hline 7. & $\begin{array}{l}\text { Murmured stop with voiceless } \\
\text { onset }\end{array}$ & $\sqrt{ }$ & $\sqrt{ }$ & $\mathrm{x}$ & $\mathrm{x}$ & $\mathrm{X}$ & $\mathrm{x}$ & $\mathrm{x}$ & $\mathrm{x}$ & $\mathrm{x}$ & $\mathrm{X}$ \\
\hline 8. & $\begin{array}{l}\text { Murmured affricate with } \\
\text { voiceless onset }\end{array}$ & $\sqrt{ }$ & $\mathrm{x}$ & $\mathrm{x}$ & $\mathrm{x}$ & $\mathrm{X}$ & $\mathrm{x}$ & $\mathrm{x}$ & $\mathrm{X}$ & $\mathrm{x}$ & $\mathrm{X}$ \\
\hline 9. & $\begin{array}{l}\text { Murmured fricative with } \\
\text { voiceless onset }\end{array}$ & $\sqrt{ }$ & $\sqrt{ }$ & $\mathrm{x}$ & $\mathrm{x}$ & $\mathrm{x}$ & $\mathrm{x}$ & $\mathrm{x}$ & $\mathrm{x}$ & $\mathrm{x}$ & $\mathrm{x}$ \\
\hline 10. & $\begin{array}{l}\text { Murmured trill/tap with } \\
\text { voiceless onset }\end{array}$ & $\sqrt{ }$ & $\mathrm{x}$ & $\mathrm{x}$ & $\mathrm{x}$ & $\mathrm{x}$ & $\mathrm{x}$ & $\mathrm{x}$ & $\mathrm{x}$ & $\mathrm{x}$ & $\mathrm{x}$ \\
\hline 11. & $\begin{array}{l}\text { Murmured lateral with } \\
\text { voiceless onset }\end{array}$ & $\sqrt{ }$ & $\mathrm{x}$ & $\mathrm{x}$ & $\mathrm{x}$ & $\mathrm{x}$ & $\mathrm{x}$ & $\mathrm{x}$ & $\mathrm{x}$ & $\mathrm{x}$ & $\mathrm{x}$ \\
\hline 12. & $\begin{array}{l}\text { Murmured stop with voiceless } \\
\text { onset }\end{array}$ & $\mathrm{x}$ & $\sqrt{ }$ & $\mathrm{x}$ & $\mathrm{x}$ & $\mathrm{X}$ & $\mathrm{x}$ & $\mathrm{x}$ & $\mathrm{x}$ & $\mathrm{x}$ & $\mathrm{x}$ \\
\hline 13. & Labialized stops and nasals & $\mathrm{x}$ & $\mathrm{x}$ & $\sqrt{ }$ & $\mathrm{x}$ & $\mathrm{x}$ & $\mathrm{x}$ & $\mathrm{x}$ & $\mathrm{x}$ & $\mathrm{x}$ & $\mathrm{x}$ \\
\hline 14. & Glottal stops & $\mathrm{x}$ & $\mathrm{x}$ & $\sqrt{ }$ & $\mathrm{x}$ & $\mathrm{x}$ & $\sqrt{ }$ & $\mathrm{x}$ & $\mathrm{x}$ & $\mathrm{x}$ & $\sqrt{ }$ \\
\hline 15. & Complex onset: $\mathrm{CX}$ & $\sqrt{ }$ & $\sqrt{ }$ & $\sqrt{ }$ & $\sqrt{ }$ & $\sqrt{ }$ & $\sqrt{ }$ & $\sqrt{ }$ & $\sqrt{ }$ & $\sqrt{ }$ & $\sqrt{ }$ \\
\hline
\end{tabular}

$[\sqrt{ }=$ presence and $\mathrm{x}=\mathrm{absence}]$ 
160 / Segmental phonological proporties...

$\mathrm{TH}=$ Thakali, $\mathrm{CH}=$ Chantyal, $\mathrm{MN}=$ Manange, $\mathrm{WT}=$ Western Tamang, $\mathrm{ET}=$ Eastern Tamang, $\mathrm{NP}=\mathrm{Nar}-\mathrm{Phu}, \mathrm{KK}=$ Kaike and $\mathrm{GR}=$ Gurung, $\mathrm{GH}=$ Ghale and $\mathrm{SK}=\mathrm{Seke}$

*very marginally distinctive or lacking full counterparts of all oral monophthongs ** not yet been identified

\section{Summary}

In this paper, we investigated some properties of basic sounds and syllable structure in Thakali and compared them with the common segmental phonological properties of Bodish as well as with the West-Bodish languages. Thakali, a shifting Tibeto-Burman language, exhibits a rich inventory of 33 segmental consonant phonemes. Such phonemes may be classified into voiceless unaspirated, voiceless aspirated, voiced murmured and voiceless murmured (murmured sound with voiceless onset). It contains six vowels with murmured voice (i.e., breathy) counterparts. It lacks phonemic nasalized vowels as well as length contrast. Thakali, a member of West-Bodish, conforms to the most of the common phonological properties of Bodish. Murmur is concomitant with tone in Bodish. Thakali, like Chantyal (Noonan 2003a: 316), presents contrasts involving voice onset time and murmur. Such contrasts are attested in stops, affricates, fricatives, trills/taps and laterals in Thakali. Unlike in Chantyal, murmur may take place with voiceless trill/tap and voiceless lateral in Thakali. Thakali, one of the members of the Gurungic cluster of West Bodish sub-section, shares many segmental phonological properties to other WestBodish languages, especially Chantyal, Manange, Gurung, Magar Kaike, Ghale, Seke, Nar-Phu, Western Tamang and Eastern Tamang. Such properties include absence of phonemic voicing contrasts and presence of retroflex series, distinct alveolar fricatives and alveolar affricates. Thakali differs from other West-Bodish languages with the exception of Chantyal mainly in terms of contrasts involving voice onset time and murmur. To conclude, Thakali as a language with sustainable identity has to be uplifted to sustainable orality. Especially, the murmured properties of the consonants have to be maintained while teaching this language for speaking as mother tongue in the community.

\section{References}

Bradley, David. 2002. The Sub-grouping of Tibeto-Burman. In Beckwith, Christopher I (ed.) Medieval Tibeto-Burman Languages. 73-112. Leiden: Brill.

Benedict, Paul. 1972. Sino-Tibetan: A Conspectus. Cambridge: Cambridge University Press.

Central Bureau of Statistics /CBS. 2012. National Population and Housing Census 2011: National Report. Kathmandu: Central Bureau of Statistics.

Eppele, John W., M. Paul Lewis, Dan Raj Regmi and Yogendra P. Yadava (eds.) 2012. Ethnologue: Languages of Nepal. Kathmandu: Central Department of Linguistics and SIL International.

Gauchan, Tej Prasad (ed.). 2061 BS. Thakali-Nepali-English Dictionary. Kathmandu: Thakali Research Centre and Thakali Service Committee (Centre).

Gauchan, Tej Prasad, Yogendra Bhattachan and Krishna Paudel. 2065BS. Nghae Kai: Kache Thi [ Our language: Class 1]. Kathmandu: Thakali Sewa Samiti, Nepal.

Georg. 1996. Marphatan Thakali. München-Newcastle: LINCOM EUROPA. 
Regmi and Regmi / 161

Glover, Warren W. 1970. Gurung Segmental Synopsis. In Hale, Austin and Pike, Kenneth L. (eds.) Tone systems of Tibeto-Burman languages of Nepal. 211-36. Urbana: University of Illinois.

Glover, Warren W. 1974. Sememic and Grammatical Structures in Gurung (Nepal). Kathmandu: The Summer Institute of Linguistics, Nepal.

Hari, Anna Maria. 1969. Thakali Phonemic Summary. Tibeto-Burman phonemic summaries, III. Kirtipur: Summer Institute of Linguistics.

Hari, Maria. 1970. Thakali Segmental Synopsis. In Hale, Austin and Pike, Kenneth L. (eds.) Tone systems of Tibeto-Burman languages of Nepal. 258-78. Urbana: University of Illinois.

Hildebrandt, Kristine A. 2004 . A Grammar and Glossary of the Manange Language. In Genetti, Carol (ed.) Tibeto-Burman Languages of Nepal: Manange and Sherpa. 9-189. Canberra: Pacific Linguistics.

Hildebrandt, Kristine A. 2005. A Phonetic Analysis of Manange Segmental and Supra-segmental Properties. Linguistics of the Tibeto-Burman Area, 28(1). 1-39.

Honda, Isao. 2002. Seke Phonology: A Comparative Study of Three Seke Dialects. Linguistics of the Tibeto-Burman Area 25. 191-210.

Honda, Isao. 2003. A Sketch of Tangbe. In Kansakar, Tej Ratna and Mark Turin (eds.) Themes in the Himalayan Languages and Linguistics. 49-64. Hiedelberg and Kathmandu: South Asia Institute and Tribhuvan University.

Khadgi, Mari-Sisko. 2010. The consonants of Ghale. A paper presented at the 31st Annual Conference of Linguistic Society of Nepal held in Tribhuvan Unversity, Kathmandu, 26-27 November, 2010.

Limbu, Kuber Singh and Sakindra Kumar Limbu. 2008. The Documentation of the Thakali Language. A Report submitted to the National Foundation for Development of Indigenous Nationalities (NFDIN), Sanchal, Lalitpur, Nepal.

Matisoff, James A. 2003. Handbook of Proto-Tibeto-Burman: System and Philosophy of SinoTibetan Reconstruction. Berkeley: University of California Press.

Mazaudon, Martine. 2003. Tamang. In Thurgood, Graham and Randy J. LaPolla (eds.) The SinoTibetan Languages. 291-314. London and New York: Routledge.

Noonan, Michael. 2003a. Chantyal. In Thurgood, Graham and Randy J. LaPolla (eds.) The SinoTibetan Languages. 315-335. London and New York: Routledge.

Noonan, Michael. 2003b. Nar-Phu. In Thurgood, Graham and Randy J. LaPolla (eds.) The SinoTibetan Languages. 336-352. London and New York: Routledge.

Noonan, Michael. 2003c. Recent Language Contact in the Nepal Himalaya. In Bradley, David, Randy LaPolla, Boyd Michailovsky and Graham Thurgood (eds.) Language Variation: Papers on Variation and Change in the Sinosphere and in the Indosphere in Honour of James A. Matisoff. Canberra: Pacific Linguistics.

Paudel, Krishna. 2008. Ghale Language: A Brief Introduction. Nepalese Linguistics 23. 168-185.

Regmi, Ambika. 2013. A Grammar of Magar Kaike. München: LINCOM EUROPA.

Regmi, Ambika. 2017. A Sociolinguistic Survey of Thakali. Kathmand: Central Department of Linguistics Tribhuvan University Linguistic Survey of Nepal (LinSuN).

Symons, Bruce. 1993. Doing Phonology. Australia: South Pacific, SIL.

Tulachan, Purna Prasad. 2069BS. Thakali ra Thakali Bhasa [Thakali and the Thakali language]. Pokhara: Puranaprasad shaikkshik Akshyakosh.

Webster, Jeff. 2007. A Preliminary Sociolinguistic Survey of Thakali. Kathmandu: Center for Nepal and Asian Studies (CNAS), Tribhuvan University. 